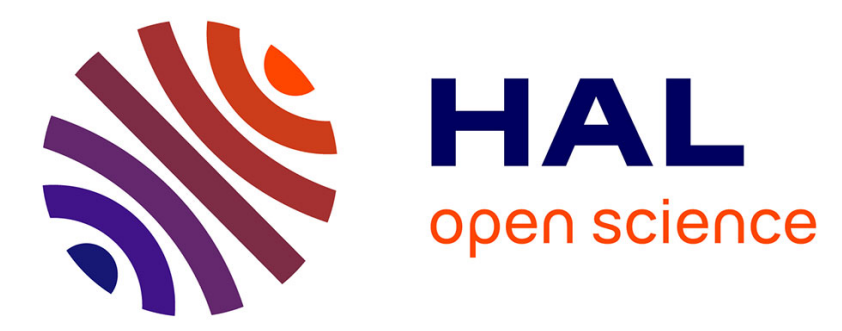

\title{
Precision farming uses typology in arable crop-oriented farms in northern France
}

\author{
Alicia Ayerdi Gotor, Elisa É. Marraccini, Christine Leclercq, Olivier Scheurer
}

\section{To cite this version:}

Alicia Ayerdi Gotor, Elisa É. Marraccini, Christine Leclercq, Olivier Scheurer. Precision farming uses typology in arable crop-oriented farms in northern France. Precision Agriculture, 2020, 21, pp.131-146. 10.1007/s11119-019-09660-y . hal-02365519

\section{HAL Id: hal-02365519 \\ https://hal.science/hal-02365519}

Submitted on 15 Nov 2019

HAL is a multi-disciplinary open access archive for the deposit and dissemination of scientific research documents, whether they are published or not. The documents may come from teaching and research institutions in France or abroad, or from public or private research centers.
L'archive ouverte pluridisciplinaire HAL, est destinée au dépôt et à la diffusion de documents scientifiques de niveau recherche, publiés ou non, émanant des établissements d'enseignement et de recherche français ou étrangers, des laboratoires publics ou privés. 


\title{
Precision farming uses typology in arable crop- oriented farms in northern France
}

\author{
Alicia Ayerdi Gotor ${ }^{1}{ }^{*}$, Elisa Marraccini ${ }^{2}$, Christine Leclercq $^{2}$ and Olivier Scheurer $^{3}$ \\ $1 \quad$ UniLaSalle Beauvais (France), AGHYLE, UP 2018.C101, ORCID 0000-0001-6725-3334 \\ 2 UniLaSalle Beauvais (France), INTERACT, UP 2018.C102 \\ 3 UniLaSalle Beauvais (France) \\ * Correspondence: alicia.ayerdi-gotor@unilasalle.fr; Tel.: +33-344062549
}

\begin{abstract}
The adoption of precision farming techniques (PFTs) has been widely studied targeting specific PFT or farming systems along with the potential benefits of these PFTs in terms of yield or input use. However, few studies have examined how PFTs are adopted and used at the farm level. In this study a preliminary investigation was made of on-farm PFT uses in the Oise region (northern France). Three main PFTs were identified in the area: Global Navigation Satellite Systems (GNSS) guidance, section control, and variable rate (VR) application. For each farm, the use of every PFT was defined by the technical characteristics of the equipment, the field operation(s) concerned, the targeted crop(s), the aim of the use, the PFT adoption drivers, and the perceived impacts by the farmers. These different variables were combined into a typology of PFT uses. The results show that most of the farms combined GNSS guidance for all technical operations and section control, whereas VR application was less common. Section control was largely used by farmers for liquid fertilizers and phytochemical spraying. The typology shows three to five types of use for each PFT, which differ in terms of technique adoption drivers, e.g. reducing on-farm work or adaptation to field morphology. According to literature, economic impacts were found to be the most frequent, however farmers seemed unable to quantify them. Social impacts such as reduced work time and fatigue were also frequent and are becoming the main motivation for using PFT on farms studied. Further research is needed to assess the use trajectories of PFT along with the motivations of each PFT use.
\end{abstract}

Keywords: Precision farming; Impacts; Adoption; Farm-level; Techniques

\footnotetext{
Acknowledgments: We warmly acknowledge the group of students in agricultural engineering "Agronomie et Territoire" at UniLaSalle for their hard work in the initial phases of the research: Hélène Callewaert, Jean Manuel Clabaut, Juliette Descotes, Lucie Deterpigny, Marie Thérèse Gässler, Estelle Harant, Pierre Lauwerier, François Mathellié, Axel Moilleron, Damien Prévost $(\dagger)$ and Hélène Vanbesalaere, as well as useful discussions with Sophie Wieruszeski and Florian Vigneron from the Oise agricultural Chamber. 23 farmers answered our questions, and many thanks to all of them. We acknowledge the editor for helpful and constructive comments. This research did not receive any specific grant from funding agencies in the public, commercial, or not-for-profit sectors.
}

\section{Introduction}


Agricultural equipment is now available that enable farmers to update management, diagnosis and optimization practices (Gavaland and Goutiers 2013). Precision farming represents a group of techniques, technologies and tools that help to improve agricultural operations, some of which can be automated. Recent reports (Awad 2016; Zarco-Tejada et al. 2014) provided an overview of the precision farming technologies and techniques (PFTs) available in terms of data acquisition, data storage, data exchange, and decision-support systems both for arable and livestock systems. Examples of these techniques and technologies include human-machine interface instruments, ownership of data, machine guidance, controlled traffic farming, and biomass monitoring.

PFTs are useful for managing the spatial and temporal variability of the fields, and can reduce the environmental impact of farm operations by optimizing the use of inputs (Reichardt and Jürgens 2009) or reducing the impact of the machines (Hallet et al. 2012). The expected impacts of Precision Farming (PF) can be grouped in three main areas: economic, environmental and social (Batte and Arnholt 2003; EPRS 2016; Reichardt and Jürgens 2009). Besides these benefits, the adoption level of PFTs is heterogeneous within countries and cropping systems (Kernecker et al. 2016; Say, et al. 2017) reflecting that the benefits are not identically perceived by farmers. Few studies are available, and mainly focus on developed countries (Say et al. 2017). Among them there are only few generalizable studies based on large random sample surveys but there are many case studies looking for the motivation for PFT adoption. In Europe, few countries have generalizable estimation on PFT adoption, among them UK where official statics exist (DEFRA 2013). In Europe, a recent study (Kernecker et al. 2016) examined the experience of PFT adoption in several European countries (France, Germany, Greece, Serbia, Spain, Netherlands, UK) and farming systems (arable, orchards, field vegetables, vineyards) in a non-random sample of farmers. This study underlined strong tendencies between high and low adopter countries and the cropping system: in low adoption countries, the non-adopters have stronger expectations on PFT to increase farm income, work comfort and support management decision. Farm size and cropping system differentiated the PFT preferences: in small farms (2-10 ha) the preferred PFT were for example robots and sensors and in larger farms (>500ha) preferred tractor GNSS, field level imagery and mapping. Other studies on PFT have been carried out at national or regional levels, for example in the UK (Awad 2016), Germany (Paustian and Theuvsen 2017; Reichardt and Jürgens 2009), Italy (Cavallo et al. 2015) and Denmark (Pedersen et al. 2004). In these studies, the focus was either on targeted farming systems (e.g. cotton-based or soybean-based systems), or in general on PFT practitioners. Outside of Europe, several studies have been conducted on PFT adoption rate, and the common characteristic of these countries is that they have large scale farms where the material return of investment is shorter and just a small optimization of the inputs or yield will have a high economic impact on farm profitability, i.e: In US the PFT adoption rate is evaluated at between 30 and 50\% of the land parcels cultivating corn or soybean (Schimmelpfennig 2016). In Brazil from 992 interviewed farmers only 45\% were using at least one PFT ( Molin 2016). In Australia in a survey of 573 famers with more than 500 ha of grain crops showed that $33 \%$ had already used yield mapping, 49\% vary fertilizer rates either manually or with computer technology, 15\% variable rate technology and 77\% have used autosteer (Llewellyn and Ouzman 2014).

The drivers of PFT adoption have also been studied. Profitability has been considered as a key driver (Melchiori et al. 2013; Swinton and Lowenberg-DeBoer 1998). Some studies have highlighted that the farm and farmer's individual characteristics also need to be taken into account, although farmer's individual characteristics do not seem to be statistically significant in some of the literature (Castle et al. 2016; Fountas et al. 2005; Paustian and 
Theuvsen 2017; Zarco-Tejada et al. 2014). In Germany, Paustian \& Theuvsen (2017) showed a correlation between farm size (more than 500 ha of arable land) and the involvement of the farmer in contract works as a complementary activity, whereas a lower arable area and rate of cereals were negatively correlated to the adoption of PF. In studies from the US and Canada studies (Daberkow and McBride 2003; Fountas et al. 2005) three other factors were found to affect adoption which were: high income, the possibility of investment and limited subsidies for agricultural products. A 2016 study stated that the potential of PF adoption in Europe is related to a high rate of cropland and cereals, a high number of hectares per working unit, along with the economic competitiveness of the region (EPRS 2016). Thus, several north western European countries have a higher potential for PFT adoption, particularly Denmark, Germany, France and the UK. Starting with a review of literature, Pierpaoli et al. (2013) analyzed ex-ante and ex-post drivers of adoption. In both cases, the main groups of adoption drivers were contingent factors (e.g. farm size), socio-demographic factors (e.g. age or education of the farmer), and economic factors. In the non-practitioner population, this review also underlined the need for references regarding PFT, e.g. in-field demonstrations, free trials, support services along with the increasing profitability of the adopted techniques. In addition, once a farmer has adopted a PF technique and has observed one or several benefits, he / she will be more likely to adopt another PF technique.

However, only partial data are currently available concerning the economic and environmental benefits of PFT (EPRS 2016). Field trials on the machine guidance impact on fertilizer overlapping have shown a reduction in overlapping but the quantity saved depends mainly on the field shape (Bousquet 2016) or heterogeneity, e.g. regarding soil quality (Hallet et al. 2012; Polling et al. 2010). Hallet et al. 2012 estimated that limiting soil compaction while using traffic controlled machinery could increase yield up to 5\% depending on soil type. In a sample of 44 fields, Larson et al. (2016) estimated a median reduction in spraying overlap of $3 \%$ for fields with a perimeter area ratio (P/A) of $0.01,9.6 \%$ for fields with $\mathrm{P} / \mathrm{A}=0.02$ and $13.5 \%$ for fields with $\mathrm{P} / \mathrm{A}$ of 0.03 . Although these thresholds are of major interest for an ex-ante estimation of the input reduction, data on the spraying conditions (e.g. wind), the optimal boom width, the number of boom sections and the speed of the information transfer between the guidance and the activation of the section control are also needed for ex-post assessment.

The expected benefits of PFT are thus often theoretical or based on experimental data only targeting one individual technique (Balafoutis et al. 2017; EPRS 2016). These results are often based on a reduction in overlapping or the treated surface, based on the geometrical theoretical surface but not on real measures (Diacono et al. 2013; EPRS 2016). They did not provide enough data regarding the conditions in which they were obtained and thus the possibilities of extrapolation, and of reference creation, are limited. This is why more information on the farmer's perception on PFT and the on-farm use of PFT are important to understand the onfarm adoption and impact of PF. In this study, on farm adoption refers not only to the ownership of an equipment with PFT but also on getting the result of using it either for its original goal (Llewellyn and Ouzman 2014) or for new uses.

The objectives of this study were to identify the on-farm PFT uses and their adoption drivers as well as their perceived benefits by farmers who have already adopted PFT, in order to determine the gap between expected benefits and the perceived benefits. This knowledge can contribute to target extension services for a better management of PFTs. PFT applied on crop-oriented farms was investigated. Three main groups of techniques 
were identified: guidance, section control, and variable rate application. These three groups correspond to the main PA techniques according to Balafoutis et al. (2017). In line with Cockburn a PFT use case was defined as the series of related interactions between the treated system and its external drivers for a particular goal, i.e. in this case, the combination of target objectives, the uses (technical operation x crop), and the context (adoption drivers) (Figure 1).

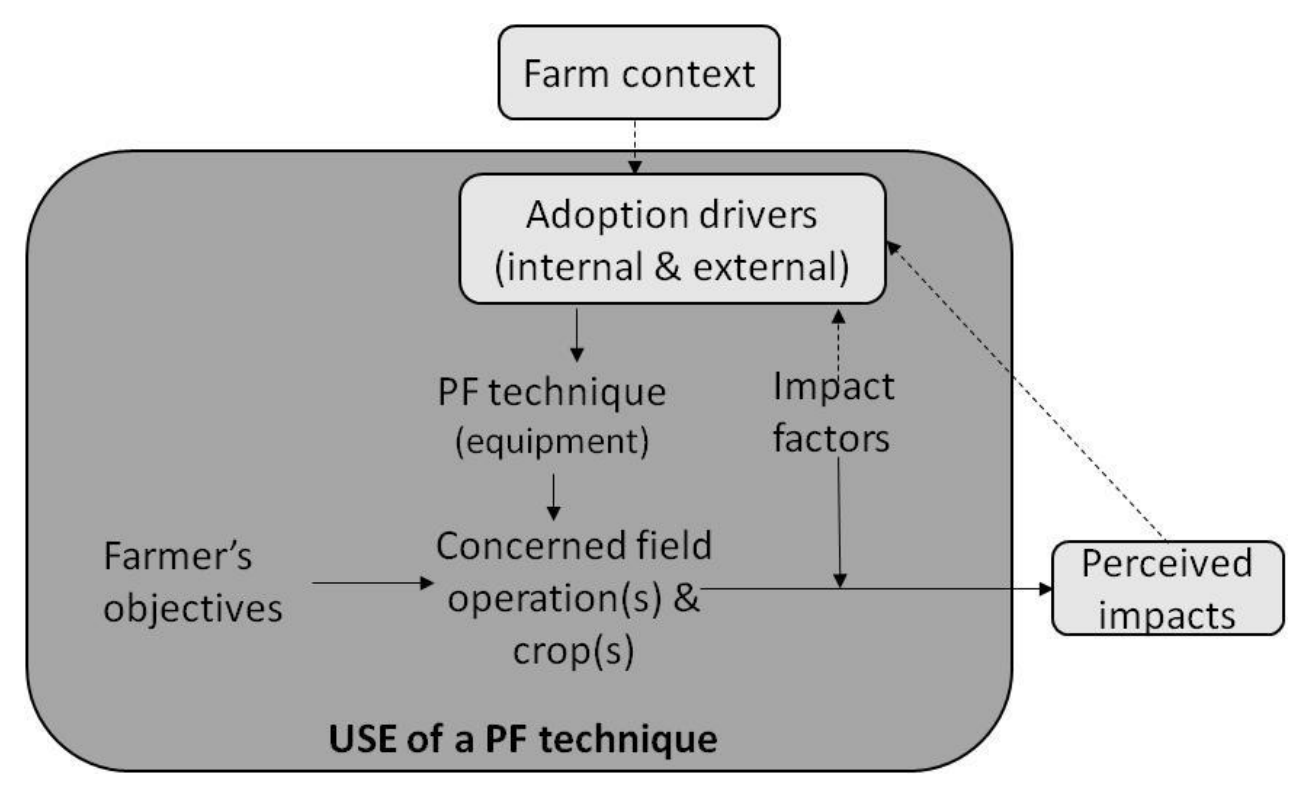

Figure 1 Analytical framework of the study. PF: precision farming

Based on this analysis of the state of the art, two main hypothesis were tested in this study. Firstly, the presence of an agricultural machinery with PFT may generate a diversity of uses of this PFT; secondly, each use of a PFT technique will generate different perceived impacts.

This research was conducted in a French case study. Few studies have been conducted in France to evaluate the PFT benefits or adoption level (Arvalis 2015). Moreover, no information on PF is provided by large scale national statistical studies in France such as agricultural censuses, which are mainly focused on the ownership and renewal of the agricultural equipment (Agreste 2016). Some reports from manufacturers or agricultural groups offer a partial view on the adoption of some PFT for instance the Invivo group in 2015 declared 150,000 ha under PF (Invivo, 2016). This work is thus intended as a preliminary study.

\section{Materials and Methods}

PFT uses in the Oise region, northern France, were investigated. This region corresponds to the NUTS (Nomenclature of Territorial Units for Statistics) level 3 in the EU administrative (EUROSTAT 2010). The Oise region is located within a high potential area for PF farming adoption (EPRS 2016; Polling et al. 2010), both due to the high share of arable crop-oriented farms, which is almost $62 \%$ compared to $23 \%$ for the rest of France (Agreste - Hauts de France 2017) and the large average farm size, which was 115 ha in 2013 compared to 61 ha in France overall (Agreste 2017). As reported by the regional Agricultural Chamber (CRAAP 2010), 40\% of farms in Oise are cereal crop-oriented (mainly soft wheat, rape seed and barley), 25\% are industrial croporiented (mainly sugar beet, potato and vegetables) and $20 \%$ are livestock-oriented (mainly dairy and cattle 
breeding). A total of 23 farmers practicing PF were questioned in autumn 2015. The surveyed farmers were randomly selected from a database of the local Chamber of Agriculture of $40 \mathrm{PF}$ practitioners in the region, who are considered as innovative due to their management of agricultural equipment.

The farm typology of the Picardy region (CRAAP 2010) was used to validate the consistency of the interviewed farmers with regional farm diversity. Interviews were semi-structured in order to obtain information on the use of PFT. The interview was conceived as a framework in which all respondents were asked the initial same questions with the same wording and the same sequence (Corbetta 2018). The interview started by outlining the objectives and the method of the study. The questions were phrased in an unambiguous way, ensuring that they would be easily understood and clarification questions were asked in order to complete the farmer discourse. Details of the main information gathered is given in Table 1.

Table 1 Description of the structured interviews conducted with the farmers.

\begin{tabular}{|c|c|c|}
\hline GENERAL QUESTION & MAIN COLLECTED DATA & OBJECTIVE \\
\hline General Farm Features - Context & $\begin{array}{l}\text { - Age, legal status, employees } \\
\text { - Farm size, Parcels (size, shape, } \\
\text { soil types, slope) } \\
\text { - Crop rotation(s)/Sequences } \\
\text { - Crop operation(s) } \\
\text { - Regulatory framework } \\
\text { - Agricultural equipment }\end{array}$ & $\begin{array}{l}\text { - To characterize the farm and the } \\
\text { user's constraints and assets that can } \\
\text { influence PFT impacts or serve as a } \\
\text { hindrance or a motivation for PFT use } \\
\text { - To detect internal factors (drawbacks } \\
\text { or levers) of PFT adoption or PFT } \\
\text { impact factors } \\
\text { - To identify the farm type through } \\
\text { crop rotation according to the regional } \\
\text { typology. }\end{array}$ \\
\hline $\begin{array}{l}\text { PFT \& Agricultural Equipment \& } \\
\text { characteristics }\end{array}$ & $\begin{array}{l}\text { - PFT used, description, } \\
\text { motivations, } \\
\text { - History of the introduction and } \\
\text { adoption } \\
\text { - Advantages/disadvantages } \\
\text { - Objectives of use } \\
\text { - Projects, and their reasons }\end{array}$ & $\begin{array}{l}\text { - To identify objectives, assets and } \\
\text { constraints for PFT (economic, social, } \\
\text { environmental point of view) } \\
\text { - To determine the PFT adoption } \\
\text { pattern and the adoption drivers }\end{array}$ \\
\hline Terms of uses for each PFT & $\begin{array}{l}\text { - Crops and fields concerned, } \\
\text { reasons } \\
\text { - Technical operations involved } \\
\text { - Origin of the information: } \\
\text { technical advice, follow-up }\end{array}$ & $\begin{array}{l}\text { - Farm surface concerned } \\
\text { - Reasons for use } \\
\text { - Effect(s)/hectare } \\
\text { - To understand impact factors }\end{array}$ \\
\hline PFT Impacts & $\begin{array}{l}\text { Observed impacts on: inputs and } \\
\text { fuel use, yields, life quality, } \\
\text { labor/crop, quality of the } \\
\text { technical operation }\end{array}$ & $\begin{array}{l}\text { To understand the perceived economic, } \\
\text { social and environmental impacts } \\
\text { (primary or secondary impacts) }\end{array}$ \\
\hline Source of information & Personal information retrieval, & To identify farmers' motivation for \\
\hline
\end{tabular}




\begin{tabular}{|l|l|l|}
\hline & reasons & adopting PF \\
\hline
\end{tabular}

Two origins were considered for the adoption drivers: internal, which take into account the farm's characteristics such as parcels (shape, heterogeneity...), specific crop operation or condition (i.e. night working) or the farmer's expectations; and the external origin such as external factors influencing the farmer's use, e.g. having contract work or a neighbour using a PFT. The internal adoption drivers for the use of a chosen PF technique may have an identified objective, whereas external adoption drivers are not directly associated with an objective.

A typology of PF use was developed based on the objectives, adoption drivers, and PFT use. The method was adapted from Landais (1998), who implemented farm typologies to illustrate the diversity of farms at a regional level. In this case, the typology was based on the PFT uses instead of the farms. This implies that each farm using several PFTs can be represented in several types. In addition, once classified by a PFT, farms were grouped according to crops and technical operations related to the techniques. Thus, a farm typology was built based on the observed combinations of PFTs uses.

The impacts of each PFT perceived by each farmer were grouped by use in order to obtain the occurrence of primary impacts in the farmers' statements. The benefits of the primary impacts were then identified. For example, in reducing overlapping, the perceived benefits were work time saving and input reduction. The final impacts classified the benefits in three impact categories: economic, social and environmental. In the previous example, time saving was classified as a social and economic final impact, whereas input reduction was environmental and economic.

\section{Results and discussion}

\section{Characterization of farms}

The 23 farms analysed (Figure 2), represent seven of the fifteen types described in the Picardy farm typology, with a majority of "diversified-cereal" and "sugar beet" types, and an average farm size (UAA) of 254 ha. 


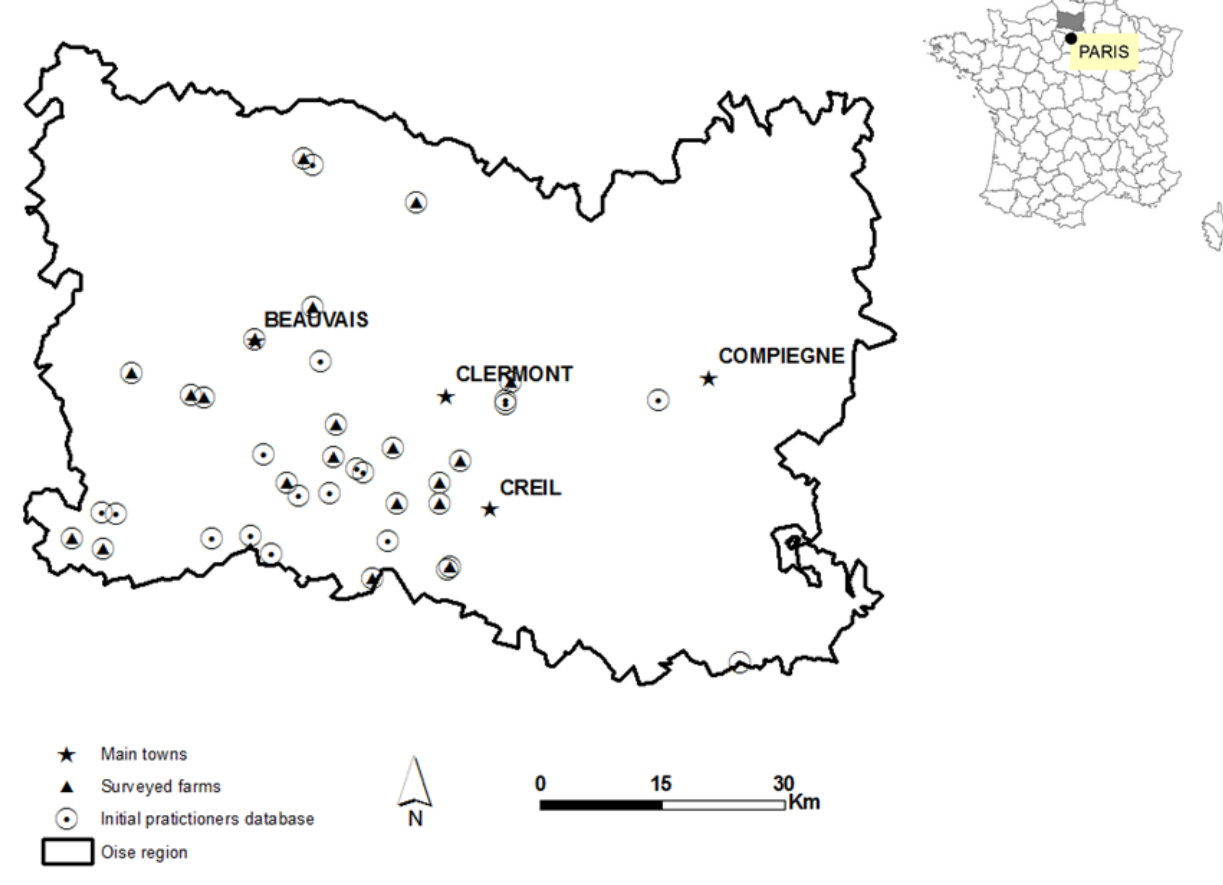

Figure 2 Distribution of the surveyed farms in the Oise region (France).

In the three Eurostat NUTS3 Picardy regions (Oise, Somme, Aisne), 13\% of farms were categorized as "diversified cereal $>100$ ha" type, and polyculture-mixed farms represented $12 \%$ (Figure 3). Each Picardy farm type is not equally represented in the region (CRAAP 2010).

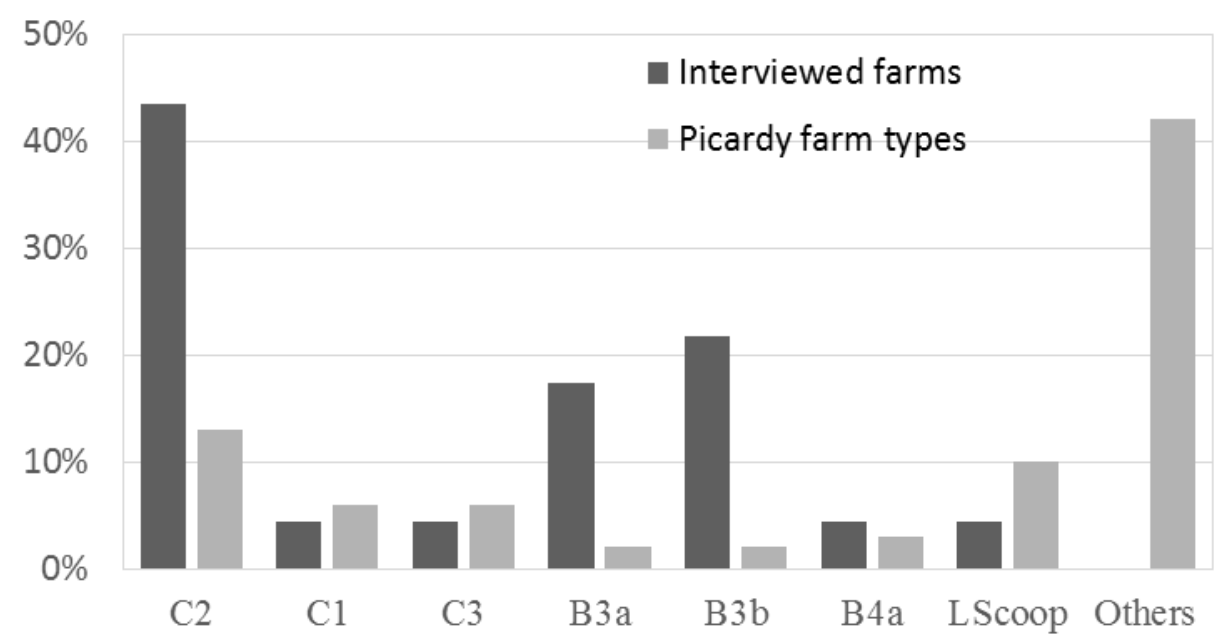

Figure 3 Farm types in the Picardy typology in the 23 farms interviewed compared to the three NUTS3 Oise, Aisne and Somme Regions.; C1: Specialised cereal farm <100ha; C2: Diversified cereal farm >100ha; C3: Specialised cereal farm >100ha; B3a: Diversified sugar beet farm 120-200ha; B3b: Diversified sugar beet farm > 200ha; B4a: Specialised sugar beet farm 110-300ha; LScoop: mixed farm; Others: livestock farms or small farms. 
Of the farms interviewed, four combinations of the three PFTs groups were observed (Figure 4a): guidance and section control of the sprayer and of the fertiliser spreader; guidance (assisted and/or manual), variable rate application and automated hoeing along with guidance. Guidance was either manual, either assisted or a combination of the two (Figure 4b). Automated intrarow hoeing was only found in two cases combined with another PFT. Almost all the farms except one used two or more PF techniques. A total of 19 out of the 23 farms combined guidance with section control. Guidance was the most adopted PFT, whereas variable rate application was the least adopted.

These findings are similar to those reported by a 2017 literature review made (Say et al. 2017), in that in both developed and developing countries guidance was the most adopted technique whereas the other PFTs were less frequently used. Despite the different socio-economical and agricultural contexts, Fountas et al. (2005) concluded that PF uses were quite similar in USA and Europe more than a decade before the same authors (Balafoutis et al. 2017) confirmed this. Guidance use and adoption is probably facilitated by the ease of use and the fact that it is an included option in the new equipment. It also facilitated the work with no precise investment of the user to make a "correct use" whereas the others PFTs require a more extensive knowledge both of the use of the PFT or an agronomical knowledge in order to be able to take the best decision (Awad 2016; Melchiori et al. 2013). In these later cases, the results of the use are not visible immediately. In addition, VR applications require combined technologies in sensor and image or data analysis and information transfer to the mechanical part of the instrument (Lepej and Rakun 2016) which still needs further technological development.

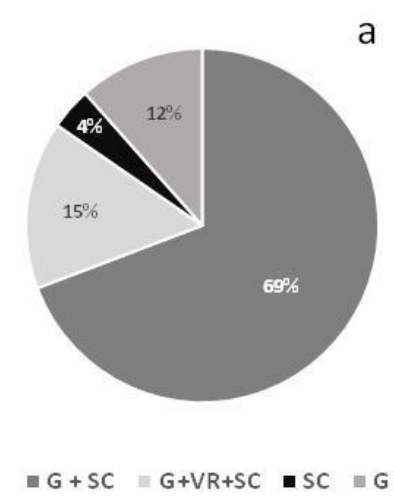

a

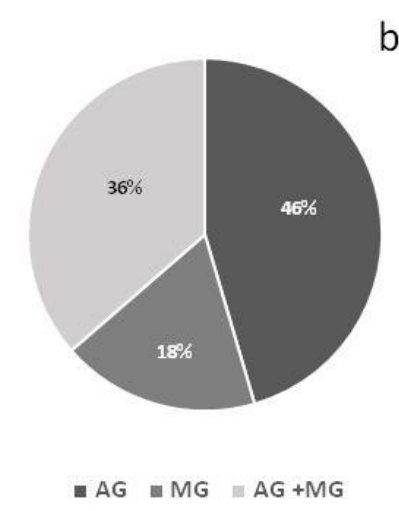

Figure 4 Distribution of the PF techniques in the 23 studied farms (a). SC: Section Control; G: Guidance; VR: Variable rate application. Types of guidance found in 23 studied farms within those that use Guidance (b): AG: Assisted Guidance; MG: Manual Guidance.

\section{Adoption drivers}

Table 2 presents the PF adoption drivers of the 23 interviewed farms. The internal drivers were more diversified than the external ones. The external drivers are not related to a specific technique, whereas internal drivers may be more specific at the beginning of adoption. Among the internal adoption drivers, except for farmers with a personal interest in new technologies, the targeted impacts mainly improved technical efficiency and wellbeing at work. These targeted impacts are similar to those found by Batte and Arnholdt (2003) and Cavallo et al. (2015), respectively. Compared to the results of Pierpaoli et al. (2013) in an ex-post assessment of PFT adoption, i.e. the practitioners, similar drivers were found apart from the socio-demographic factors. However, in 
this case, these drivers were less general, such as soil quality. Namely, the study found more focus on the heterogeneity of the soil quality in general and not the specific quality of one soil type.

Some drivers were related to a specific element of farming or cropping system, such as the sharing of machines or equipment with other farmers or the crop management practices (e.g. conservation agriculture). These drivers related to the farming system are less investigated in the literature on the adoption drivers at a national level. In fact, the analysis has often focused on the individual practitioner characteristics and on general characteristics of the farm business rather than on the farm or crop management (Batte and Arnholt 2003; Reichardt and Jürgens 2009; Say et al. 2017).

Table 2 Most frequent PF adoption drivers related to different techniques and targeted impacts in a sample of 23 surveyed farms in Oise (northern France). SC: Section Control; G: Guidance; VR: Variable rate application.

Drivers
PF Technique(s)

\section{Main targeted}

impacts

\begin{tabular}{|c|c|c|c|}
\hline \multirow{7}{*}{$\begin{array}{l}\text { Z } \\
Z \\
\frac{\alpha}{1} \\
\text { 至 }\end{array}$} & One person for a large cultivated surface & G \& SC & Wellbeing at work \\
\hline & $\begin{array}{l}\text { Constraining field properties (shape, slopes) or } \\
\text { environment (river proximity) }\end{array}$ & & Work time saving \\
\hline & $\begin{array}{l}\text { One (or more) element of crop management practices } \\
\text { requiring higher precision }\end{array}$ & $\mathrm{G}$ and/or $\mathrm{SC}$ & $\begin{array}{l}\text { Wellbeing at work } \\
\text { Technical efficiency }\end{array}$ \\
\hline & High soil heterogeneity & VR & Technical efficiency \\
\hline & Farmer's interest in new technologies & G \&/or SC \&/or VR & \\
\hline & Need to renew a piece of machinery & G \&/or SC \&/or VR & Technical efficiency \\
\hline & Need to increase free time & G \&/or SC \&/or VR & Technical efficiency \\
\hline \multirow{4}{*}{ 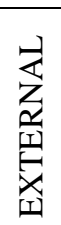 } & Shared ownership & G \&/or SC \&/or VR & \\
\hline & Belonging to a $\mathrm{CUMA}^{(2)}$ & G \&/or SC \&/or VR & \\
\hline & Environmental constraints & G \&/or SC \&/or VR & \\
\hline & Investment aid(s) & G \&/or SC \&/or VR & \\
\hline
\end{tabular}

(1) Spraying at night, need for field marking, crop and cover crop seeding in conservation agriculture, mechanical weeding on sugar beet

(2) CUMA: a cooperative for sharing agricultural equipment

Precision farming techniques use typology

The analysis of the PF uses in the interviewed farms led to a typology of uses. Table 3 shows these types along with the different combinations of a PF technique with field operations and farmers objectives.

Various levels of PF implementation where highlighted. A basic level was the use of a PFT for just one field operation, such as guidance for sowing or harvesting or automated hoeing for sugar beet. The highest level was the use of a PFT for assisted guidance for all field operations.

Looking at the combinations of these use types on each farm (Table 4), the simplest combination was the use of autoguidance only for crop sowing. Intermediate levels of PFT uses were the combination of two different PFTs 
for one or several field operations, such as the assisted guidance and section control for spraying. The most complex combination found was the assisted guidance of most of operations, with section control of the sprayer or solid fertilizer spreader, often with a variable application nitrogen rate or harvest guidance. The two farms where VR was found, practice both no-till and ploughing, have an UAA of around 200 ha, and their parcels are heterogeneous. In these conditions the VR is used in combination with the two other PFTs in order to be more precise and efficient. For the practitioners, the two main objectives when implementing these PFTs were to improve work comfort (wellbeing and time saving) and to decrease inputs, except for automated hoeing in the case of sugar beet.

Table 3. Use types of each PF technique in the interviewed farms; C1: Specialised cereal farm <100ha; C2: Diversified cereal farm >100ha; C3: Specialised cereal farm >100ha; B3a: Sugar beet diversified farm 120200ha; B3b: Sugar beet diversified farm > 200ha; B4a: Specialised sugar beet farm 110-300ha; LScoop: mixed farm

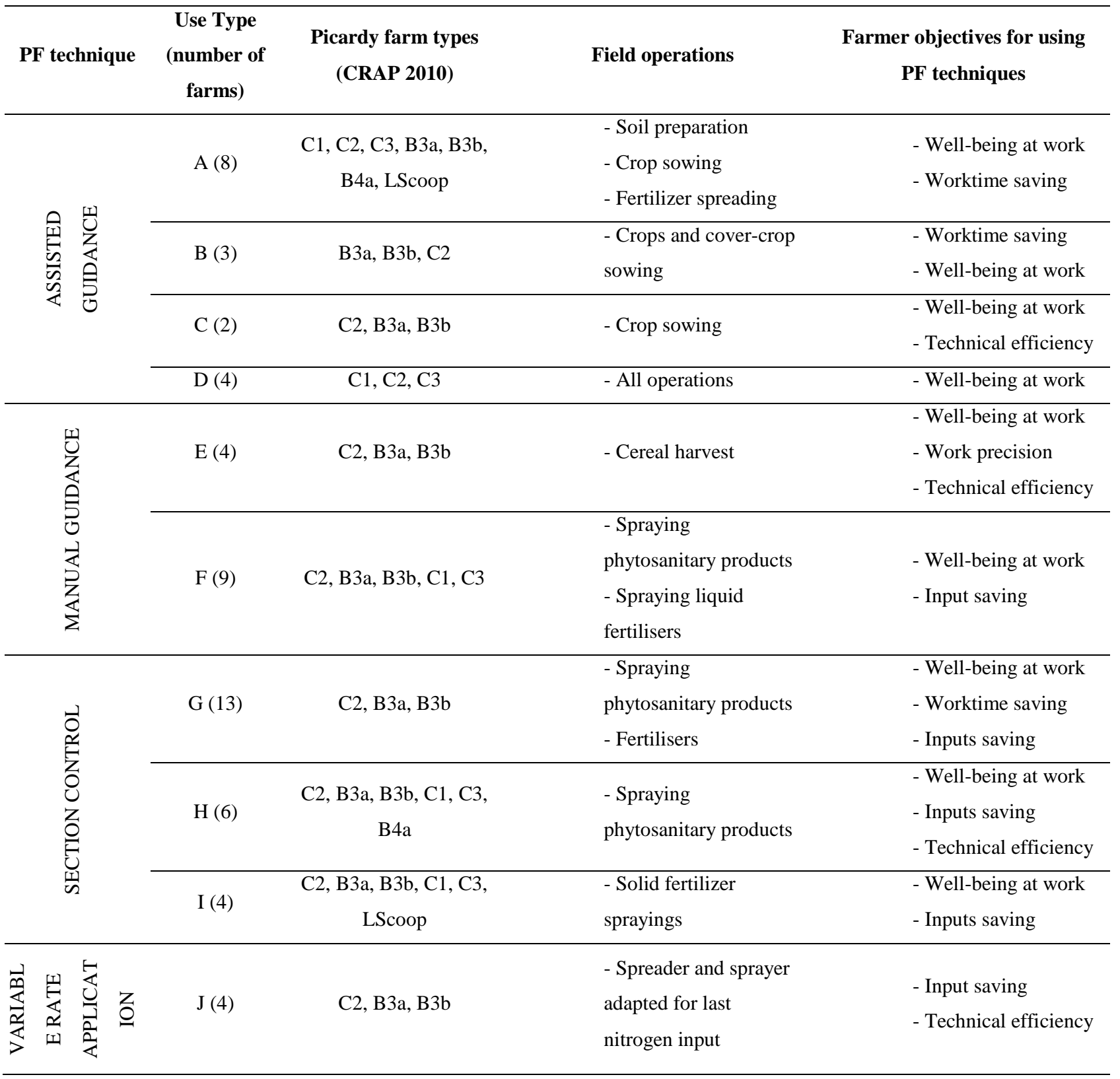




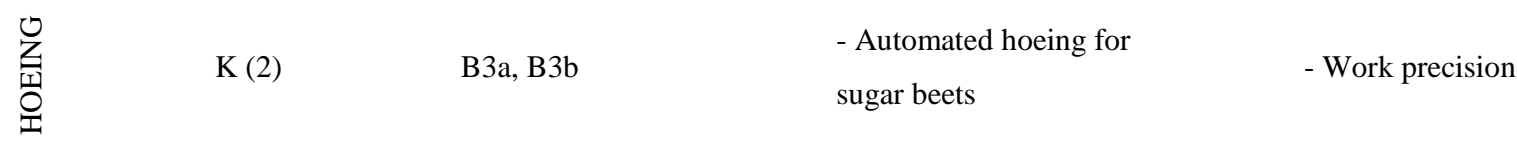

While in this study the VR technical operations were spraying and sowing with guidance in the US, as evidenced by Say et al.'s review (2017) who focused on fertilisation and lime applications. This difference may be due first, to the farming systems, which are mainly winter cereal-based or diversified in Oise, France and mainly cornsoybean-based in US. Second, the farm size, since fields and farms in the US are bigger than in France (Lowder et al. 2016), which uses a different crop management in terms of fertilisation, because the heterogeneity of soil is less important. However, it is also due to the fact that VR technologies are more common in the US than in France, where other tools to manage nitrogen fertilisation are implemented (Jeuffroy et al. 2013) and nitrogen use policies are more restrictive (European Parliament 2000), thus as a consequence, nitrogen management has already been optimized. Finally, according to the Ohio farm survey (Batte and Arnholt 2003) as well as in one review (Say et al. 2017), the increased profitability appeared to be one of the main motivations for PFT adoption, whereas this was the case in this survey.

Table 4: On farm combination of PFTs uses

\begin{tabular}{lll}
\hline Number of farms & Number of uses & Combination of PFTs used \\
\hline 3 & 2 & Assisted guidance + Section control sprayer \\
1 & 2 & Assisted guidance + Section control spreader \\
4 & 2 & Manual guidance + Section control sprayer \\
4 & 3 & Assisted \& Manual guidance + Section control sprayer \\
1 & 4 & Assisted \& Manual guidance + Section control sprayer+ Hoeing \\
1 & 2 & Section control sprayer + Automated hoeing \\
2 & 3 & Assisted guidance + Section control sprayer + Section control spreader \\
1 & 2 & Section control sprayer + Section control spreader \\
1 & 1 & Assisted guidance \\
1 & 2 & Assisted \& Manual guidance \\
2 & 4 & Assisted \& Manual guidance + Section control sprayer + Variable rate \\
2 & 3 & Assisted guidance + Section control sprayer+ Variable rate \\
\hline
\end{tabular}

Whereas these results (Table 3) demonstrate that farmers have different uses of PFTs, the reasons why a famer use a PFT for one technical operation and other famer use it for another technical operation or all technical operations were not investigated. Which means that the reasons for not using a PFT for all the possible uses are unknown. Two hypothesis can be made: first, they have a specific need so they have acquire the PFT and use it to fulfil their need (i.e. in a no-tillage system, reducing soil compaction by passing always in the same row with all equipment (Balafoutis et al. 2017)); secondly, that to use a PFT for each technical operation requires a knowledge, which is different within technical operation, so farmers are not at the same learning level to be able to apply at any moment the PFT (Busse et al. 2014). 
A generalisation of this typology of on-farm PFT uses is not possible for two main reasons. First, it is only based on 23 farms, thus multicriteria statistics cannot be applied. Secondly, the combination of uses is not homogeneously and equally distributed within the interviewed farms. However, the identified types could be tested through a larger study also including other more quantitative technical surveys.

Impacts

At least two primary perceived impacts per PFT use were found, except for types E and K, which are linked to specific field operations (harvest and hoeing) (Table 5). In most of the use types, the induced impacts, once identified in the PF use, are shared among most of the farmer practitioners, except for better application conditions which also requires the particular need of the farmer to implement it, for example, for night spraying. Finally, the most recurrent impact was the economic category, followed by social and environmental ones. Most of the PFT uses combine these three categories.

Table 5 Perceived impacts related to each use type, light grey indicates that between 50 and $75 \%$ of the population affected by this use identified this impact, dark grey indicates that over $75 \%$ of the population identified this impact for this type of use. The types of PFT uses are described in Table 3. 


\begin{tabular}{|c|c|c|c|c|c|c|c|c|c|c|c|}
\hline & & 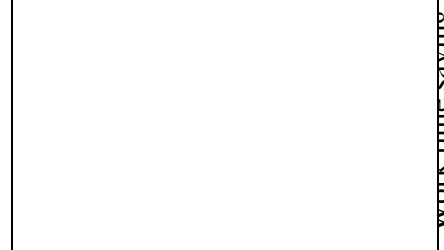 & $\begin{array}{l}20 \\
0 \\
0 \\
0 \\
0 \\
5 \\
5 \\
5 \\
0\end{array}$ & $\begin{array}{l}y \\
0 \\
0 \\
3 \\
0 \\
0 \\
00 \\
.0 \\
0 \\
0 \\
0 \\
0 \\
3\end{array}$ & 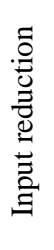 & 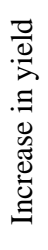 & 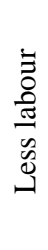 & 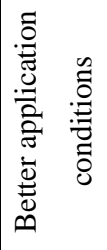 & 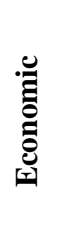 & 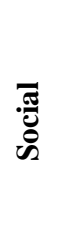 & 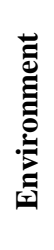 \\
\hline \multirow{11}{*}{$\begin{array}{l}\text { ASSISTED } \\
\text { GUIDANCE }\end{array}$} & \multirow{4}{*}{ A } & Avoiding field marking & & & & & & & $\mathrm{x}$ & $\mathrm{x}$ & \\
\hline & & Less concentration required & & & & & & & & $\mathrm{x}$ & \\
\hline & & Reduction of overlapping & & & & & & & $\mathrm{x}$ & & $\mathrm{x}$ \\
\hline & & Work precision & & & & & & & $\mathrm{x}$ & & \\
\hline & \multirow{2}{*}{$\mathrm{B}$} & Work precision & & & & & & & $\mathrm{x}$ & & \\
\hline & & Less concentration required & & & & & & & & $\mathrm{x}$ & \\
\hline & \multirow{3}{*}{$\mathrm{C}$} & Less concentration required & & & & & & & & $\mathrm{x}$ & \\
\hline & & Reduction of overlapping & & & & & & & $\mathrm{x}$ & & $\mathrm{x}$ \\
\hline & & Work precision & & & & & & & $\mathrm{x}$ & & \\
\hline & \multirow{2}{*}{$\mathrm{D}$} & Less concentration required & & & & & & & & $\mathrm{x}$ & \\
\hline & & Reduction of overlapping & & & & & & & $\mathrm{x}$ & & $\mathrm{x}$ \\
\hline \multirow{3}{*}{$\begin{array}{l}\text { MANUAL } \\
\text { GUIDANCE }\end{array}$} & $\mathrm{E}$ & "Run and round" harvesting & & & & & & & $\mathrm{x}$ & $\mathrm{x}$ & \\
\hline & \multirow{2}{*}{$\mathrm{F}$} & Field marking avoiding & & & & & & & $\mathrm{x}$ & $\mathrm{x}$ & \\
\hline & & Night work possible & & & & & & & $\mathrm{x}$ & & $\mathrm{x}$ \\
\hline \multirow{8}{*}{$\begin{array}{l}\text { SECTION } \\
\text { CONTROL }\end{array}$} & \multirow{3}{*}{ G } & Herbicide reduction & & & & & & & $\mathrm{x}$ & & $\mathrm{x}$ \\
\hline & & Less concentration required & & & & & & & & $\mathrm{x}$ & \\
\hline & & Faster workflow & & & & & & & $\mathrm{x}$ & $\mathrm{x}$ & \\
\hline & \multirow{3}{*}{$\mathrm{H}$} & Less concentration required & & & & & & & & $\mathrm{x}$ & \\
\hline & & Reduction of overlapping & & & & & & & $\mathrm{x}$ & & $\mathrm{x}$ \\
\hline & & Night work possible & & & & & & & $\mathrm{x}$ & & $\mathrm{x}$ \\
\hline & \multirow{2}{*}{$\mathrm{I}$} & Reduction of overlapping & & & & & & & $\mathrm{x}$ & & $\mathrm{x}$ \\
\hline & & Night work possible & & & & & & & $\mathrm{x}$ & & $\mathrm{x}$ \\
\hline VARIABLE & \multirow{3}{*}{$\mathrm{J}$} & Less concentration required & & & & & & & & $\mathrm{x}$ & \\
\hline RATE & & Avoiding overlapping in corners & & & & & & & $\mathrm{x}$ & & $\mathrm{x}$ \\
\hline APPLICATION & & Faster work flow & & & & & & & $\mathrm{x}$ & $\mathrm{x}$ & \\
\hline HOEING & $\mathrm{K}$ & Work precision & & & & & & & $\mathrm{x}$ & & \\
\hline \multicolumn{3}{|l|}{ Total occurrences } & 6 & 7 & 7 & 4 & 4 & 3 & 19 & 12 & 10 \\
\hline
\end{tabular}

Several PF use types also concern a reduction in overlapping in technical operations (spraying, fertilizer application, sowing). The farmers interviewed were unable to quantify the reduction in overlapping, except for a few cases who referred to spraying (less than 5\% of input reduction). In the literature an estimation of the input reduction due to less overlapping mainly concerns edges of the field perimeter, as indicated by Larson et al. ( 2016) and Luck et al. (2010) for spraying. For planting Velandia et al. (2013) showed that potential savings varied by farm sizes and distribution of field types in a farming operation. Knowledge on input reduction is of interest not only for farmers but also for decision-makers and extension services to estimate the on-farm and local impacts of PFT adoption. In EU countries, the LPIS (Land Parcel Identification System) database could be useful for an ex-ante assessment of the field perimeter area ratio (Levavasseur et al. 2016).

Social impacts also appear to be important in terms of the reduction of requirements: less concentration, night work possible for some field operations, or a faster workflow. In the French context, less concentration during field operations refers to being less tired at the end of the day and being able to perform other activities after the 
task. These impacts contrast with the farmers' perceptions of the benefits of PF techniques, observed in another study (Kernecker et al. 2016), such as biodiversity conservation, reduction in harvest losses or being able to follow regulations, which are cited in more than $50 \%$ of responses, whereas farmers' work comfort was considered important only by $38 \%$ of respondents.

\section{Conclusions}

On-farm uses, adoption drivers and perceived impacts of PFT were investigated, in a sample of Oise farms (northern France). The novelty of this approach is the analysis of how farmers really use PFTs. This approach revealed the combinations of PFTs adopted by farmers for their technical operations. Studies so far have only analysed the adoption drivers or the impacts of each technique separately, without considering the actual use and the combinations used in farms. The presence of a PFT generates a diversity of uses in terms of guidance and section control, highlighting that farmers in Oise region use these PFTs in a gradient going from one specific operation to all the field operations. At the farm level, in only one case was a single use type identified (assisted guidance) and a maximum of four use types were identified. VR application and automated hoeing were less common and mainly used by large sugar-beet oriented farms. Each use of a PFT technique generated different perceived impacts. Social impacts (wellbeing at work and decreased work time) were more commonly perceived than expected (except for the variable rate application) and seemed to be strong drivers for the adoption of PF techniques, more than the economic impacts. Agronomic, economic and environmental impacts were also perceived but almost never quantified. Guidance and section control of spraying were the most adopted techniques, probably because of their multiple impacts and their multiple adoption drivers. In addition, the use of this equipment does not need additional information such as an application map or any supplementary knowledge. The results demonstrate that there is a potential to increase the use of PFT in Oise farms even in those farms that are already equipped with machinery, as all possible uses are not covered for an adopted PFT. However, these dynamics need to be supported by technical advisors or agro-equipment suppliers in order to optimize PFT uses. This optimization could be supported by an increase of local references for each PFT and PFT use on input reduction and economic gains also in terms of information costs as well as an increase in exchanges on PFT uses among farmers to boost collective learning.

Conflicts of Interest: "The authors declare no conflict of interest"

\section{References}

Agreste. (2016). L'équipement dans les exploitations agricoles. http://agreste.agriculture.gouv.fr/IMG/pdf/primeur334.pdf. Accessed 14 September 2018

Agreste. (2017). Panorama du monde agricole, forestier, alimentaire - Série Hauts de France. http://draaf.hauts-de-france.agriculture.gouv.fr/IMG/pdf/2-exploitations-agricoles_cle08b514.pdf. Accessed 14 September 2018

Agreste - Hauts de France. (2017). Memento de la statistique agricole. http://draaf.hauts-defrance.agriculture.gouv.fr/IMG/pdf/memento-2017_cle02595f.pdf. Accessed 14 September 2018

Arvalis. (2015). Agriculture de Précison. Editions Arvalis. Paris (France).114 pp. 
Awad, S. (2016). A review of the past, present and future of precision agriculture in the UK (Research Report No. 87). UK: AHDB Cereals \& Oilseeds. https://cereals.ahdb.org.uk/media/1126475/rr87.pdf

Balafoutis, A., Beck, B., Fountas, S., Vangeyte, J., Wal, T., Soto, I., Gómez-Barbero, M., Barnes, A., \& Eory, V. (2017). Precision Agriculture Technologies Positively Contributing to GHG Emissions Mitigation, Farm Productivity and Economics. Sustainability, 9(8), 1339. doi:10.3390/su9081339

Batte, M. T., \& Arnholt, M. W. (2003). Precision farming adoption and use in Ohio: case studies of six leadingedge adopters. Computers and Electronics in Agriculture, 38(2), 125-139. doi:10.1016/S0168-1699(02)00143-6

Busse, M., Doernberg, A., Siebert, R., Kuntosch, A., Schwerdtner, W., König, B., \& Bokelmann, W. (2014). Innovation mechanisms in German precision farming. Precision Agriculture, 15(4), 403-426. doi:10.1007/s11119-013-9337-2

Castle, M. H., Lubben, B. D., \& Luck, J. D. (2016). Factors Influencing the Adoption of Precision Agriculture Technologies by Nebraska Producers. Presentations, Working Papers, and Gray Literature: Agricultural Economics, Paper 49.

Cavallo, E., Ferrari, E., Bollani, L., \& Coccia, M. (2015). Attitudes and Behaviour of Adopters of Technological Innovations in Agricultural Tractors: A Case Study in Italian Agricultural System. Agricultural Systems, 130, 44-54. doi:http://dx.doi.org/10.1016/j.agsy.2014.05.012

Cockburn, A. (1997). Structuring Use cases with goals. Journal of object-oriented programming, 10(5), 56-62.

Corbetta, P. (2018). Social Research: Theory, Methods and Techniques. SAGE publications. London (UK). doi:10.4135/9781849209922

CRAAP. (2010). Présentation des systèmes d'exploitation agricole de Picardie. Chambre Régionale d'Agriculture de Picardie. http://www.hautsdefrance.chambres-agriculture.fr/fileadmin/user_upload/Hauts-deFrance/029_Inst-Hauts-de-France/Exploitation-

agricole/Rubrique_\%C3\%A9conomique/presentation_systemes_EA_dePicardie.pdf. Accessed 12 May 2017

Daberkow, S. G., \& McBride, W. D. (2003). Farm and Operator Characteristics Affecting the Awareness and Adoption of Precision Agriculture Technologies in the US. Precision Agriculture, 4(2), 163-177. doi:10.1023/A:1024557205871

DEFRA. (2013). Farm practices survey October 2012 - current farming issues. England: Department for Environment Food and Rural Affairs. https://www.gov.uk/government/statistics/farm-practices-survey-october2012-current-farming-issues

Diacono, M., Rubino, P., \& Montemurro, F. (2013). Precision nitrogen management of wheat. A review. Agronomy for Sustainable Development, 33(1), 219-241. doi:10.1007/s13593-012-0111-z

EPRS. (2016). Precision agriculture and the future of farming in Europe. Scientific Foresight Study. Brussels, European Parliament Research Service. http://www.europarl.europa.eu/RegData/etudes/STUD/2016/581892/EPRS_STU(2016)581892_EN.pdf.

European Parliament. Directive 2000/60/EC of the European Parliament and of the Council of 23 October 2000 establishing a framework for Community action in the field of water policy., OJ L 327 (2000). http://data.europa.eu/eli/dir/2000/60/oj/eng. Accessed 4 December 2018

EUROSTAT. (2010). RAMON - Reference And Management Of Nomenclatures. NUTS (Nomenclature of Territorial Units for Statistics), by regional level, version 2010 (NUTS 2010). http://ec.europa.eu/eurostat/ramon/nomenclatures/index.cfm?TargetUrl=LST_CLS_DLD\&StrNom=NUTS_33\& StrLanguageCode $=\mathrm{EN}$

Fountas, S., Blackmore, S., Ess, D., Hawkins, S., Blumhoff, G., Lowenberg-Deboer, J., \& Sorensen, C. G. (2005). Farmer Experience with Precision Agriculture in Denmark and the US Eastern Corn Belt. Precision Agriculture, 6(2), 121-141. doi:10.1007/s11119-004-1030-z 
Gavaland, A., \& Goutiers, V. (2013). L'agriculture de précision: applications et perspectives en grandes cultures et prairies. http://prodinra.inra.fr/record/211868. Accessed 7 February 2017

Hallet, P., Balana, B., \& Towers, W. (2012). Studies to inform policy development with regard to soil degradation: Subproject A: Cost curve for mitigation of soil compaction (No. Defra SP1305 (CTE 1024)). The James Hutton Institution. https://www.google.com/url?sa=t\&rct=j\&q=\&esrc=s\&source=web\&cd=2\&ved=2ahUKEwj7quz17rdAhVFUhoKHUYcD84QFjABegQICBAC\&url=http\%3A\%2F\%2Frandd.defra.gov.uk\%2FDocument.aspx \%3FDocument\%3D10022_SP1305SubprojectACostcurveformitigationofsoilcompaction.pdf\&usg=AOvVaw2ptI isfxLctij3QLQN4fh9. Accessed 13 September 2018

Invivo. (2016). Focus sur l'agriculture de précision. https://www.invivo-group.com/fr/focus-sur-lagriculture-deprecision. Accessed 7 February 2017

Jeuffroy, M. H., Gate, P., Machet, J. M., \& Recous, S. (2013). Gestion de l'azote en grandes cultures: les connaissances et outils disponibles permettent-ils de concilier exigencesagronomiques et environnementales? Cahiers Agricultures, 22(4). doi:https://doi.org/10.1684/agr.2013.0639

Kernecker, M., Knierim, A., \& Wurbs, A. (2016). Report on farmers' needs, innovative ideas and interests , SmartAKIS.

https://www.google.com/url?sa=t\&rct=j\&q=\&esrc=s\&source=web\&cd=1\&cad=rja\&uact=8\&ved=2ahUKEwjs7 ver1dXdAhVMUBoKHSX8COgQFjAAegQIABAC\&url=https\%3A\%2F\%2Fwww.smart-akis.com\%2Fwpcontent $\% 2$ Fuploads $\% 2$ F2017\%2F02\%2FD2.2.-Report-on-farmersneeds.pdf\&usg=AOvVaw0ZOHCCXN_SmAEkAjSfA73X. Accessed 17 October 2017

Landais, E. (1998). Modelling farm diversity: new approaches to typology building in France. Agricultural Systems, 58(4), 505-527. doi:10.1016/S0308-521X(98)00065-1

Larson, J. A., Velandia, M. M., Buschermohle, M. J., \& Westlund, S. M. (2016). Effect of field geometry on profitability of automatic section control for chemical application equipment. Precision Agriculture, 17(1), 1835. doi:10.1007/s11119-015-9404-y

Lepej, P., \& Rakun, J. (2016). Simultaneous localisation and mapping in a complex field environment. Biosystems Engineering, 150, 160-169. doi:10.1016/j.biosystemseng.2016.08.004

Levavasseur, F., Martin, P., Bouty, C., Barbottin, A., Bretagnolle, V., Thérond, O., et al. (2016). RPG Explorer: A new tool to ease the analysis of agricultural landscape dynamics with the Land Parcel Identification System. Computers and Electronics in Agriculture, 127, 541-552. doi:10.1016/j.compag.2016.07.015

Llewellyn, R., \& Ouzman, J. (2014). Adoption of Precision Agriculture-related Practices: Status, Opportunities and the Role of Farm Advisors. Montpellier, France: CSIRO. https://grdc.com.au/resources-and-publications/allpublications/publications/2014/12/adoption-of-precision-agriculture-related-practices. Accessed 12 September 2018

Lowder, S. K., Skoet, J., \& Raney, T. (2016). The Number, Size, and Distribution of Farms, Smallholder Farms, and Family Farms Worldwide. World Development, 87, 16-29. doi:10.1016/j.worlddev.2015.10.041

Luck, J. D., Pitla, S. K., Shearer, S. A., Mueller, T. G., Dillon, C. R., Fulton, J. P., \& Higgins, S. F. (2010). Potential for pesticide and nutrient savings via map-based automatic boom section control of spray nozzles. Computers and Electronics in Agriculture, 70(1), 19-26. doi.org/10.1016/j.compag.2009.08.003

Melchiori, R. J. M., Albarenque, S. M., \& Kemerer, A. C. (2013). Uso, adopción y limitaciones de la agricultura de precisión en Argentina. Presented at the Curso Int. Agricultura de Precision, Manfredi, Córdoba, Argentina. https://www.google.com/url?sa=t\&rct=j\&q=\&esrc=s\&source=web\&cd=3\&cad=rja\&uact=8\&ved=2ahUKEwj2s YLpiNbdAhVPlxoKHTn4AUsQFjACegQIBBAC\&url=https\%3A\%2F\%2Finta.gob.ar\%2Fsites\%2Fdefault\%2Ff iles\%2Fscript-tmp-

inta_uso_adopcin_y_limitaciones_de_la_agricultura_de_.pdf\&usg=AOvVaw1uZoGsVtvkE2L_-xF-wEw1

Molin, J. (2016, August 2). Precision Agriculture in Latin America. Presented at the INFO AG Conference, St. Louis, MO, USA. https://www.infoag.org/presentations/2378.pdf. Accessed 13 September 2018 
Paustian, M., \& Theuvsen, L. (2017). Adoption of precision agriculture technologies by German crop farmers. Precision Agriculture, 18(5), 701-716. doi:10.1007/s11119-016-9482-5

Pedersen, S. M., Fountas, S., Blackmore, B. S., Gylling, M., \& Pedersen, J. L. (2004). Adoption and perspectives of precision farming in Denmark. Acta Agriculturae Scandinavica, Section B - Soil \& Plant Science, 54(1), 28. doi:10.1080/09064710310019757

Pierpaoli, E., Carli, G., Pignatti, E., \& Canavari, M. (2013). Drivers of Precision Agriculture Technologies Adoption: A Literature Review. 6th International Conference on Information and Communication Technologies in Agriculture, Food and Environment (HAICTA 2013), 8, 61-69. doi:10.1016/j.protcy.2013.11.010

Polling, B., Herold, L., \& Volgman, A. (2010). Typology of farms and regions in EU states assessing the impacts of Precision Farming-Technologies in EU-farms, FutureFarm Project (p. 53pp.).

Reichardt, M., \& Jürgens, C. (2009). Adoption and future perspective of precision farming in Germany: results of several surveys among different agricultural target groups. Precision Agriculture, 10(1), 73-94. doi:10.1007/s11119-008-9101-1

Say, S. M., Keskin, M., Sehri, M., \& Sekermi, Y. E. (2017). Adoption of Precision Agriculture Technologies in Developed and Developing Countries (pp. 41-49). Presented at the International Science and Technology Conference (ISTEC), Berlin, Germany.

Schimmelpfennig, D. (2016). Farm Profits and the Adoption of Precision Agriculture (Economic Research Report No. 217). USDA Economic Research Service.

Swinton, S. M., \& Lowenberg-DeBoer, J. (1998). Evaluating the Profitability of Site-Specific Farming. Journal of Production Agriculture, 11(4), 439-446. doi:10.2134/jpa1998.0439

Velandia, M., Buschermohle, M., Larson, J. A., Thompson, N. M., \& Jernigan, B. M. (2013). The economics of automatic section control technology for planters: A case study of middle and west Tennessee farms. Computers and electronics in agriculture, 95, 1-10. doi.org/10.1016/j.compag.2013.03.006

Zarco-Tejada, P. J., Hubbard, N., \& Loudjani, P. (2014). Precision Agriculture: An Opportunity for EU Farmers-Potential Support with the CAP 2014-2020. Joint Research Centre (JRC) of the European Commission. dx.doi.org/10.2861/58758 